\title{
Morphological Traits Influence the Uptake Ability of Priority Pollutant Elements by Hypnum cupressiforme and Robinia pseudoacacia Leaves
}

\author{
Fiore Capozzi ${ }^{1, *(\mathbb{D}}$, Anna Di Palma ${ }^{2}$, Maria Cristina Sorrentino ${ }^{1}$, Paola Adamo ${ }^{2}$, \\ Simonetta Giordano ${ }^{1, *}$ and Valeria Spagnuolo ${ }^{1}$ \\ 1 Dipartimento di Biologia, Università di Napoli Federico II, Via Cintia 4, 80126 Napoli, Italy; \\ mariacristina.sorrentino@unina.it (M.C.S.); valeria.spagnuolo@unina.it (V.S.) \\ 2 Dipartimento di Agraria, Università di Napoli Federico II, Via Università 100, 80055 Portici (NA), Italy; \\ anna.dipalma@unina.it (A.D.P.); paola.adamo@unina.it (P.A.) \\ * Correspondence: fiore.capozzi@unina.it (F.C.); simonetta.giordano@unina.it (S.G.); \\ Tel.: +39-0816-79119 (S.G.)
}

Received: 12 December 2019; Accepted: 27 January 2020; Published: 29 January 2020

\begin{abstract}
In this paper, a biomonitoring survey of airborne priority pollutant elements was carried out using leaves of native black locust and moss bags filled with Hypnum cupressiforme. The aims of the work were (i) to evaluate if mosses and leaves provide similar information regarding the accumulation of the elements of environmental concern (As, $\mathrm{Be}, \mathrm{Cd}, \mathrm{Cr}, \mathrm{Cu}, \mathrm{Hg}, \mathrm{Mo}, \mathrm{Ni}, \mathrm{Pb}, \mathrm{Sb}, \mathrm{Se}, \mathrm{V}, \mathrm{Zn}, \mathrm{Tl}$ ); (ii) to evaluate if leaf traits are significantly involved in the uptake mechanisms. Hypnum transplants showed elemental contents generally higher than R. pseudoacacia leaves, despite the shorter exposure time. Moss accumulated larger amounts of elements linked to PM and the resuspension of soil dust. Based on the calculation of deposition flux for each element, $R$. pseudoacacia showed lower values for most elements-except $\mathrm{Cr}$, Mo and $\mathrm{Zn}$-indicating that uptake takes place both by deposition on the leaf surface and absorption via the root. Leaf traits (micromorphology of surface) play an important role in the interception and retention of PM-linked elements. Hypnum transplanted in bags was confirmed to be a powerful bio-accumulator of airborne elements; by contrast, $R$. pseudoacacia, with a smooth surface and scarce trichomes, showed a limited ability in airborne element retention. Therefore, widely diffused species, well-adapted to anthropized environments, such as black locust, not always can be considered as good biomonitors. The results are discussed in comparison to other vascular plant species used in biomonitoring studies.
\end{abstract}

Keywords: leaf traits; deposition flux; moss bags; airborne trace elements

\section{Introduction}

The emission to atmosphere of metal(loid)s can be of natural (e.g., volcanoes, erosion processes, fires) and anthropogenic origin (exploitation of geological resources, energy production, oil burning, transports in general and intensive agricultural systems). Their delivery to the atmosphere is mainly associated with particulate matter (PM) strongly contributing to the depletion of air quality (WHO, 2013). European Union identifies the poor air quality as one of the principal causes of premature death in the EU and allowed wide-ranging legislation to reduce harmful pollutants in the air (2004/107/EC and 2008/50/EC). Presently, besides gaseous pollutants (e.g., $\mathrm{NO}_{x}, \mathrm{CO}, \mathrm{O}_{3}, \mathrm{SO}_{2}$ ) and $\mathrm{PM}$, only a few other atmospheric contaminants (e.g., $\mathrm{Pb}, \mathrm{Cd}, \mathrm{As}, \mathrm{Ni}, \mathrm{Hg}$ and benzo[a]pyrene) are continuously monitored.

Campania Region (southern Italy) is one of the 20 administrative districts of Italy; this countryside has undergone in the last about 50 years deep changes in the use of natural resources due to fast, disordered and massive urbanization with consequent increase in industrial, commercial settlements 
and traffic fluxes. The result of this transformation is a mixed patchwork of lands, where agricultural landscapes are strictly linked to industrial and commercial areas. This situation affects air composition and pollution due to the release to atmosphere of organic and inorganic molecules not routinely measured by the local pollution monitoring network, evaluating only a limited set of pollutants (e.g., $\mathrm{NO}_{2}, \mathrm{CO}, \mathrm{PM}_{10}, \mathrm{PM}_{2.5}, \mathrm{O}_{3}, \mathrm{SO}_{2}, \mathrm{C}_{6} \mathrm{H}_{6}$ ).

The use of biomonitoring systems applied to vegetation has been widely used by many researchers to circumvent the difficulties of the direct measurement of specific pollutants in the air, providing raw data and elaborations on the presence, deposition and accumulation of non-monitored or emerging pollutants [1]. Compared to physic-chemical devices, this set of methods use flexible experimental designs and higher numbers of testing sites-compensating for the lower precision of each single measure [2-6]. Native and transplanted mosses and lichens and tree leaves are among the most utilized biomonitors of inorganic, mainly metal(loid)s, and organic contaminants (e.g., PAHs, dioxins). These plant groups develop different physiology and water relations. Moss and lichen species, in fact, lack roots and depend for water and nutrients on atmospheric wet and dry depositions; for this reason, the accumulation of airborne pollutants is strictly related to air composition. In addition, they are well-known (especially mosses) for their ability to entrap airborne particles-a channel for a wide range of pollutants, including metal(loids) [7,8]. Instead, higher plants have roots and hold at least two ways of entrance for pollutants: the aerial pathway, via deposition on leaf canopy and entrance in the tissues by stomata, and the soil pattern, via root absorption, being therefore connected to these two environmental compartments. Among the ecological traits to be considered in the uptake of pollutants, the SLA (i.e., the leaf surface to mass ratio) is of paramount importance, since most pollutants and-in particular-metal(loids) travel linked to PM material of various sizes, from the micro to the nano scale.

To date, many recent researches have assessed that for metal(loid)s and PAHs the uptake ability of mosses and lichens is mostly related to the ability to intercept and hold particulate matter [9-11] and to the specific features of cell walls [12,13]. Therefore, moss and lichen vitality does not alter metal uptake [14], since most of these elements are passively adsorbed to the thalli in form of PM. Consequently, many research projects (e.g., Mossclone) and survey plans adopted the use of devitalized moss and lichen, also because of the higher reproducibility and lower variability of the analytical results [4,15-18]. In a previous paper, Ares et al. [19] reviewed the capacity of different species of moss to accumulate contaminants, evidencing that Hypnum cupressiforme was one of the most employed species especially in southern Europe, generally lacking Sphagnum, considered the first choice. In addition, as demonstrated by González and Pokrovsky [12] H. cupressiforme has, together with Sphagnum, the best performance in the adsorption of $\mathrm{Cu}, \mathrm{Cd}, \mathrm{Ni}, \mathrm{Pb}$ and $\mathrm{Zn}$ and is suggested as one of the most natural adsorbents of heavy metals. All these reasons have encouraged our research team to follow using this moss species.

In this paper, the accumulation of 15 elements, mainly included in the EPA Priority Pollutant List, were evaluated in two biomonitors; i.e., leaves of native Robinia pseudoacacia and shoots of Hypnum cupressiforme devitalized and transplanted in bags, in target sites selected in the Campania Region (southern Italy). The aims of the work were (i) to evaluate if mosses and leaves provide similar information regarding the accumulation of the elements investigated, regardless the different exposure time, (ii) if the two biomonitors behave differently in the enrichment of specific elements or groups of elements, and (iii) if leaf traits are considerably involved in the uptake mechanisms.

\section{Experiments}

\subsection{Study Area}

The study area (Table S1, Figure S1) is located north of Napoli and is characterized by a complex and intermingled mixture of residential, agricultural, industrial settlements and related road networks. Until the 1950s, this area was devoted to agriculture, but after the Second World War its original land use began to change under the pressure of city expansion and economic recovery. The area was 
already under study in a research project aimed at the development of a phytoremediation protocol of agricultural polluted soils (Life-ECOREMED). Three additional sites from a proximal natural area-a woodland in Arpaise (Benevento province) - were used as background sites, for comparison with the test sites (see Table S1, Figure S1).

\subsection{Experimental Design, Collection of Plant Material, Bags Preparation and Exposure}

Following the exposure protocol adopted by Capozzi et al. 2016a [3], sub-spherical moss bags were prepared, filled with $500 \mathrm{mg}$ of oven-devitalized moss Hypnum cupressiforme Hedw, to have a moss density of $10 \mathrm{mg} / \mathrm{cm}^{2}$ [16]. The moss was collected in a pristine area, the Taburno-Camposauro Regional Park (1000 m.a.s.l., Table S1, Figure S1). The moss bags were exposed in triplicate in eight sites (Site 1 to 8 ) for six weeks, starting in July 2016. Ten samples of devitalized, unexposed moss were analyzed to assess pre-exposure metal contents (BL_M). This was necessary to determine the enrichment of moss tissue, as the difference between pre- and post-exposure contents of each element. Robinia pseudoacacia L., is a tree species naturalized in all temperate regions of North America, Europe and Southern Africa. It is well-adapted to dry and polluted soils [20]; moreover, it proved able to accumulate PAHs in the leaves [21]. Leaves of $R$. pseudoacacia were collected at the end of the vegetative season (November 2016). The leaves (30 leaves around the canopy at 4-5 $\mathrm{m}$ from the ground) were collected at each exposure site, within $5 \mathrm{~m}$ from the hanged moss bags (also exposed at $4 \mathrm{~m}$ above ground); leaves from background sites (BL_R 1 to 3) were also collected in November 2016 to assess baseline element contents.

\subsection{Analytical Procedures}

After exposure, the moss material removed from each nylon bag was oven-dried at $40{ }^{\circ} \mathrm{C}$, processed and analyzed separately. Similarly, R. pseudoacacia leaves from each site were treated as a composite sample and three subsamples were obtained per each site. Leaves were dried at $40{ }^{\circ} \mathrm{C}$; milled and homogenized using a Retsch PM200 ball mill equipped with agate pockets. For metal and metalloid analysis, pre- and postexposure plant samples were mineralized with ACS-grade $\mathrm{HNO}_{3}$ for $1 \mathrm{~h}$ and then with aqua regia (ACS-grade $\mathrm{HCl}-\mathrm{HNO}_{3}$ with a volume ratio of 1:3) in a boiling water bath $\left(95^{\circ} \mathrm{C}\right)$ for $1 \mathrm{~h}$. Sample solutions were analyzed using a Perkin Elmer Elan 6000 inductively coupled plasma (ICP) mass spectrometer. All concentrations were reported on a dry weight basis. Procedural blanks were usually below detection limits; tobacco leaves (CTA-OTL 1) and M3 reference moss from the Finnish Forest Research Institute [22] were used to check the accuracy and precision of the digestion and ICP analysis procedure. The elements included in the EPA priority pollutant list (As, $\mathrm{Cd}, \mathrm{Cr}, \mathrm{Cu}, \mathrm{Hg}, \mathrm{Mo}, \mathrm{Ni}, \mathrm{Pb}, \mathrm{Sb}, \mathrm{Se}, \mathrm{Zn}$ ) plus $\mathrm{Al}$ and the REE Ce, La, Y, were analyzed; the percentages of recovery ranged between 85 and $115 \%$.

\subsection{SEM Observations}

Mature leaves of R. pseudoacacia were collected from tree branches at the end of the vegetative season, gently dried at room temperature; small pieces were cut with scissors and mounted on stubs with double-sided adhesive tape. Cuts were then coated with C-Au and observed under an environmental SEM FEI QUANTA 200 working at high vacuum mode.

\subsection{Data Analysis}

Basic statistics and figure elaborations were obtained using Microsoft Office Excel 2010 and the software STATISTICA (StatSoft, 2008). The elements were considered accumulated in moss when the post exposure content exceeded the initial concentration plus 2SD [15]. To estimate the level of pollution at each site, element contents were normalized to the maximum between 0 and 1 and summed to obtain the normalized elemental load at each site. A Wilcoxon matched pairs test [23] was performed to compare element contents in moss and Robinia over all sites. 
The daily deposition flux in the two species was calculated as follows:

$$
\Theta \mathrm{DF}=\mathrm{M}_{\mathrm{acc}} /(\mathrm{S} \times \mathrm{d})
$$

where $\Theta D F$ is the deposition flux (ng m $\left.{ }^{-2} \mathrm{~d}^{-1}\right) ; \mathrm{M}_{\mathrm{acc}}$ is the amount of each pollutant (expressed as ng) accumulated during the exposure period, obtained by subtracting the pollutant amount before exposure $\mathrm{M}_{0}$ from that measured after the exposure $\mathrm{M}_{\mathrm{f}} ; \mathrm{S}$ is the exposed surface of the organism (i.e., leaf area), expressed as $\mathrm{m}^{2}$; $\mathrm{d}$ is the duration of exposure, expressed as days. Leaf area was calculated based on previous reports $[24,25]$

\section{Results and Discussion}

\subsection{Metal Contents and Enrichment in Moss and Black Locust}

For H. cupressiforme, we considered both element content and accumulation; for R. pseudoacacia we only considered the content, being it a native species. Average metal contents measured in moss pre(BL_M) and post-exposure material, and in the leaves of $R$. pseudoacacia collected at the eight tested sites and at the background site (BL_R 1-3) are reported in Table 1.

To compare the uptake in moss and black locust leaves, a PCA (Figure 1) was carried out based on the element loads in both species; the projection of cases splits moss and black locust samples along the first axis explaining more than $64 \%$ variance, while axis 2 only accounts for about $9 \%$ variance (Figure 1a). The PCA gives evidence that the moss contents are generally higher than those of black locust, despite the shorter exposure time of the moss bags ( 6 weeks) compared to the average life span of black locust leaves (about seven months). In addition, considering the projection of variables (elements), the majority is directed toward moss samples, except the Mo, As and $\mathrm{Zn}$ vectors (Figure 1b).

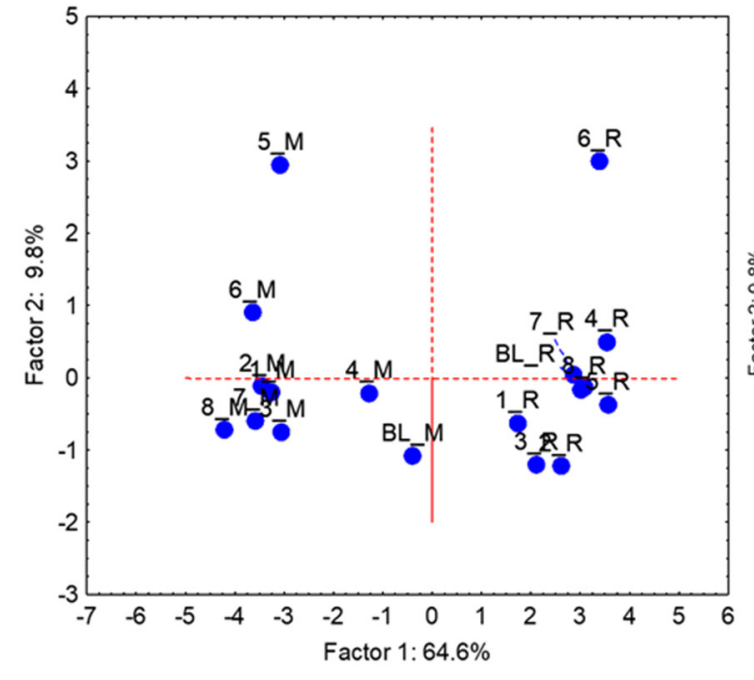

(a)

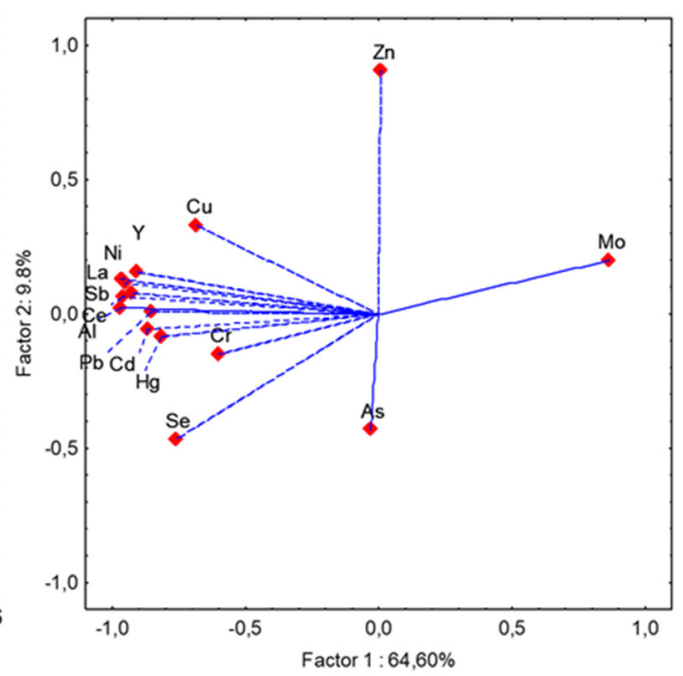

(b)

Figure 1. Principal Component Analysis of elemental content in R. pseudoacacia leaves and $H$. cupressiforme transplants (M) in the eight sites considered. Site and plant material distribution (a); vectors of elements (b). 
Table 1. Mean \pm SD of the element contents $\left(\mathrm{mg} \mathrm{Kg}^{-1}, \mathrm{n}=3\right)$ in $R$. pseudoacacia leaves $(\mathrm{R})$ and H. cupressiforme transplants (M) in the eight considered sites plus baseline elemental content for both biomonitors (BL). Significant differences according to Wilcoxon matched pairs test: ${ }^{*} p<0.05,{ }^{* *} p<0.01$.

\begin{tabular}{|c|c|c|c|c|c|c|c|c|c|c|c|c|c|c|c|}
\hline & $\mathrm{Al}^{* *}$ & As & $C d^{* *}$ & $\mathrm{Ce}{ }^{* *}$ & $\mathrm{Cr}^{* *}$ & $\mathrm{Cu}$ * & $\mathrm{Hg}$ ** & $\mathrm{La}^{* *}$ & Mo ** & $\mathrm{Ni}^{* *}$ & $\mathbf{P b} * *$ & $\mathrm{Sb}^{* *}$ & $\mathrm{Se}^{*}$ & $\mathbf{Y}^{* *}$ & $\mathrm{Zn}$ \\
\hline 1_R & $300 \pm 20$ & $0.2 \pm 0.1$ & $\begin{array}{c}0.02 \pm \\
0.00\end{array}$ & $0.7 \pm 0.2$ & $2.2 \pm 0.1$ & $8.6 \pm 0.1$ & $\begin{array}{c}0.05 \pm \\
0.01\end{array}$ & $0.5 \pm 0.1$ & $1.3 \pm 0.2$ & $0.3 \pm 0.1$ & $1.8 \pm 0.2$ & $\begin{array}{c}0.09 \pm \\
0.02\end{array}$ & $\begin{array}{c}0.52 \pm \\
0.02\end{array}$ & $\begin{array}{c}0.15 \pm \\
0.01\end{array}$ & $28 \pm 0.9$ \\
\hline 2_R & $200 \pm 10$ & $0.5 \pm 0.4$ & $\begin{array}{c}0.01 \pm \\
0.00\end{array}$ & $0.4 \pm 0.1$ & $3.7 \pm 1.5$ & $5.2 \pm 0.6$ & $\begin{array}{c}0.06 \pm \\
0.00\end{array}$ & $0.2 \pm 0.0$ & $2.5 \pm 0.2$ & $0.3 \pm 0.2$ & $1.2 \pm 0.1$ & $\begin{array}{c}0.12 \pm \\
0.00\end{array}$ & $\begin{array}{c}0.33 \pm \\
0.11\end{array}$ & $\begin{array}{c}0.08 \pm \\
0.00\end{array}$ & $24 \pm 1.2$ \\
\hline 3_R & $433 \pm 57$ & $0.4 \pm 0.2$ & $\begin{array}{c}0.01 \pm \\
0.00\end{array}$ & $0.9 \pm 0.2$ & $3.1 \pm 0.4$ & $5.9 \pm 0.3$ & $\begin{array}{c}0.04 \pm \\
0.02\end{array}$ & $0.4 \pm 0.2$ & $1.7 \pm 0.1$ & $0.4 \pm 0.1$ & $1.9 \pm 0.5$ & $\begin{array}{c}0.12 \pm \\
0.01\end{array}$ & $\begin{array}{c}0.40 \pm \\
0.02\end{array}$ & $\begin{array}{c}0.17 \pm \\
0.02\end{array}$ & $19 \pm 0.1$ \\
\hline 4_R & $200 \pm 27$ & $0.3 \pm 0.1$ & $\begin{array}{c}0.01 \pm \\
0.00\end{array}$ & $0.2 \pm 0.0$ & $3.1 \pm 0.3$ & $9.1 \pm 0.4$ & $\begin{array}{c}0.01 \pm \\
0.00\end{array}$ & $\begin{array}{c}0.07 \pm \\
0.01\end{array}$ & $2.4 \pm 0.1$ & $0.7 \pm 0.0$ & $0.1 \pm 0.0$ & $\begin{array}{c}0.04 \pm \\
0.01\end{array}$ & $\begin{array}{c}0.23 \pm \\
0.01\end{array}$ & $\begin{array}{c}0.02 \pm \\
0.00\end{array}$ & $35 \pm 1.9$ \\
\hline 5_R & $430 \pm 10$ & $0.3 \pm 0.1$ & $\begin{array}{c}0.01 \pm \\
0.00\end{array}$ & $0.1 \pm 0.0$ & $2.8 \pm 0.0$ & $6.6 \pm 0.1$ & $\begin{array}{c}0.02 \pm \\
0.00\end{array}$ & $\begin{array}{c}0.05 \pm \\
0.01\end{array}$ & $2.5 \pm 0.1$ & $0.4 \pm 6.7$ & $0.6 \pm 0.1$ & $\begin{array}{c}0.04 \pm \\
0.01\end{array}$ & $\begin{array}{c}0.33 \pm \\
0.03\end{array}$ & $\begin{array}{c}0.03 \pm \\
0.00\end{array}$ & $25 \pm 0.8$ \\
\hline 6_R & $180 \pm 54$ & $0.1 \pm 0.0$ & $\begin{array}{c}0.01 \pm \\
0.00\end{array}$ & $0.5 \pm 0.2$ & $2.6 \pm 0.1$ & $8.6 \pm 0.4$ & $\begin{array}{c}0.03 \pm \\
0.00\end{array}$ & $0.5 \pm 0.1$ & $3.5 \pm 0.5$ & $0.7 \pm 0.1$ & $0.5 \pm 0.3$ & $\begin{array}{c}0.15 \pm \\
0.01\end{array}$ & $\begin{array}{c}0.10 \pm \\
0.00\end{array}$ & $\begin{array}{c}0.14 \pm \\
0.02\end{array}$ & $63 \pm 4.5$ \\
\hline 7_R & $166 \pm 57$ & $0.3 \pm 0.2$ & $\begin{array}{c}0.01 \pm \\
0.00\end{array}$ & $0.4 \pm 0.1$ & $2.7 \pm 0.2$ & $6.9 \pm 0.1$ & $\begin{array}{c}0.03 \pm \\
0.01\end{array}$ & $0.2 \pm 0.0$ & $2.3 \pm 0.2$ & $0.8 \pm 1.3$ & $0.8 \pm 0.2$ & $\begin{array}{c}0.24 \pm \\
0.08\end{array}$ & $\begin{array}{c}0.27 \pm \\
0.01\end{array}$ & $\begin{array}{c}0.12 \pm \\
0.01\end{array}$ & $31 \pm 1.5$ \\
\hline 8_R & $100 \pm 24$ & $0.5 \pm 0.3$ & $\begin{array}{c}0.05 \pm \\
0.01\end{array}$ & $0.3 \pm 0.1$ & $3.1 \pm 0.1$ & $6.7 \pm 0.1$ & $\begin{array}{c}0.03 \pm \\
0.01\end{array}$ & $0.2 \pm 0.0$ & $2.5 \pm 0.3$ & $0.3 \pm 0.1$ & $0.8 \pm 0.1$ & $\begin{array}{c}0.30 \pm \\
0.02\end{array}$ & $\begin{array}{c}0.23 \pm \\
0.01\end{array}$ & $\begin{array}{c}0.07 \pm \\
0.00\end{array}$ & $39 \pm 1.5$ \\
\hline BL_R & $102 \pm 20$ & $0.1 \pm 0.0$ & BDL & $0.1 \pm 0.0$ & $2.5 \pm 0.1$ & $5.8 \pm 0.0$ & $\begin{array}{c}0.05 \pm \\
0.02\end{array}$ & $\begin{array}{c}0.07 \pm \\
0.01\end{array}$ & $0.7 \pm 0.2$ & $2.6 \pm 0.1$ & $0.2 \pm 0.0$ & $\begin{array}{c}0.01 \pm \\
0.00\end{array}$ & $\begin{array}{c}0.24 \pm \\
0.02\end{array}$ & $\begin{array}{c}0.02 \pm \\
0.00\end{array}$ & $18 \pm 0.7$ \\
\hline 1_M & $\begin{array}{c}2385 \pm \\
100\end{array}$ & $\begin{array}{c}0.35 \pm \\
0.07\end{array}$ & $\begin{array}{c}0.13 \pm \\
0.02\end{array}$ & $\begin{array}{c}3.95 \pm \\
0.09\end{array}$ & $\begin{array}{c}3.93 \pm \\
0.20\end{array}$ & $\begin{array}{c}11.9 \pm \\
1.95\end{array}$ & $\begin{array}{c}0.05 \pm \\
0.03\end{array}$ & $\begin{array}{c}1.94 \pm \\
0.03\end{array}$ & $\begin{array}{c}0.23 \pm \\
0.03\end{array}$ & $\begin{array}{c}1.7 \pm \\
0.26\end{array}$ & $\begin{array}{c}5.34 \pm \\
0.31\end{array}$ & $\begin{array}{c}0.82 \pm \\
0.16\end{array}$ & $\begin{array}{c}0.46 \pm \\
0.05\end{array}$ & $\begin{array}{c}0.76 \pm \\
0.02\end{array}$ & $\begin{array}{c}20.6 \pm \\
1.56\end{array}$ \\
\hline 3_M & $\begin{array}{c}2166 \pm \\
200\end{array}$ & $\begin{array}{c}0.5 \pm \\
0.36\end{array}$ & $\begin{array}{c}0.12 \pm \\
0.02\end{array}$ & $\begin{array}{c}3.83 \pm \\
0.22\end{array}$ & $\begin{array}{c}3.81 \pm \\
0.09\end{array}$ & $\begin{array}{c}11.2 \pm \\
0.37\end{array}$ & $\begin{array}{c}0.05 \pm \\
0.04\end{array}$ & $\begin{array}{c}1.9 \pm \\
0.02\end{array}$ & $\begin{array}{c}0.27 \pm \\
0.01\end{array}$ & $\begin{array}{c}1.56 \pm \\
0.11\end{array}$ & $\begin{array}{c}7.11 \pm \\
0.73\end{array}$ & $\begin{array}{c}0.89 \pm \\
0.07\end{array}$ & $\begin{array}{c}0.46 \pm \\
0.05\end{array}$ & $\begin{array}{c}0.71 \pm \\
0.03\end{array}$ & $\begin{array}{c}16.9 \pm \\
0.56\end{array}$ \\
\hline 4_M & $\begin{array}{c}1666 \pm \\
50\end{array}$ & $0.2 \pm 0.0$ & $\begin{array}{c}0.1 \pm \\
0.00\end{array}$ & $\begin{array}{c}2.72 \pm \\
0.09\end{array}$ & $\begin{array}{c}3.66 \pm \\
0.15\end{array}$ & $\begin{array}{c}7.8 \pm \\
0.57\end{array}$ & $\begin{array}{c}0.06 \pm \\
0.04\end{array}$ & $\begin{array}{c}1.26 \pm \\
0.07\end{array}$ & $\begin{array}{c}0.21 \pm \\
0.02\end{array}$ & $\begin{array}{c}1.6 \pm \\
0.22\end{array}$ & $\begin{array}{c}3.11 \pm \\
0.17\end{array}$ & $\begin{array}{c}0.65 \pm \\
0.09\end{array}$ & $\begin{array}{c}0.36 \pm \\
0.11\end{array}$ & $\begin{array}{c}0.54 \pm \\
0.03\end{array}$ & $\begin{array}{c}20.3 \pm \\
1.5\end{array}$ \\
\hline 5_M & $\begin{array}{c}2100 \pm \\
100\end{array}$ & $\begin{array}{c}0.3 \pm \\
0.14\end{array}$ & $\begin{array}{c}0.15 \pm \\
0.01\end{array}$ & $\begin{array}{c}3.41 \pm \\
0.18\end{array}$ & $\begin{array}{c}3.90 \pm \\
0.02\end{array}$ & $\begin{array}{c}11.0 \pm \\
0.28\end{array}$ & $\begin{array}{c}0.06 \pm \\
0.03\end{array}$ & $\begin{array}{c}1.65 \pm \\
0.03\end{array}$ & $\begin{array}{c}0.26 \pm \\
0.02\end{array}$ & $\begin{array}{c}2.33 \pm \\
0.11\end{array}$ & $\begin{array}{c}6.59 \pm \\
2.73\end{array}$ & $\begin{array}{c}0.77 \pm \\
0.08\end{array}$ & $\begin{array}{c}0.36 \pm \\
0.05\end{array}$ & $\begin{array}{c}0.79 \pm \\
0.05\end{array}$ & $\begin{array}{c}57.8 \pm \\
8.25\end{array}$ \\
\hline 6_M & $\begin{array}{c}2600 \pm \\
200\end{array}$ & $0.2 \pm 0.1$ & $\begin{array}{c}0.12 \pm \\
0.01\end{array}$ & $\begin{array}{c}4.65 \pm \\
0.21\end{array}$ & $\begin{array}{c}3.73 \pm \\
0.11\end{array}$ & $\begin{array}{c}8.91 \pm \\
0.35\end{array}$ & $\begin{array}{c}0.06 \pm \\
0.02\end{array}$ & $\begin{array}{c}2.22 \pm \\
0.05\end{array}$ & $\begin{array}{c}0.24 \pm \\
0.02\end{array}$ & $\begin{array}{c}1.7 \pm \\
0.11\end{array}$ & $\begin{array}{c}4.42 \pm \\
0.11\end{array}$ & $\begin{array}{c}1.15 \pm \\
0.13\end{array}$ & $\begin{array}{c}0.46 \pm \\
0.05\end{array}$ & $\begin{array}{c}0.98 \pm \\
0.02\end{array}$ & $\begin{array}{c}46.4 \pm \\
3.33\end{array}$ \\
\hline 7_M & $\begin{array}{c}1900 \pm \\
324\end{array}$ & $0.5 \pm 0.2$ & $\begin{array}{c}0.13 \pm \\
0.03\end{array}$ & $\begin{array}{c}3.36 \pm \\
0.42\end{array}$ & $\begin{array}{c}3.66 \pm \\
0.15\end{array}$ & $\begin{array}{c}9.68 \pm \\
1.11\end{array}$ & $\begin{array}{c}0.05 \pm \\
0.03\end{array}$ & $\begin{array}{c}1.59 \pm \\
0.19\end{array}$ & $\begin{array}{c}0.18 \pm \\
0.01\end{array}$ & $\begin{array}{c}2.23 \pm \\
0.57\end{array}$ & $\begin{array}{c}10.9 \pm \\
4.03\end{array}$ & $\begin{array}{c}1.32 \pm \\
0.16\end{array}$ & $\begin{array}{c}0.43 \pm \\
0.11\end{array}$ & $\begin{array}{c}0.74 \pm \\
0.05\end{array}$ & $\begin{array}{c}20.4 \pm \\
1.12\end{array}$ \\
\hline 8_M & $\begin{array}{c}1833 \pm \\
542\end{array}$ & $\begin{array}{c}0.15 \pm \\
0.07\end{array}$ & $\begin{array}{c}0.33 \pm \\
0.04\end{array}$ & $\begin{array}{c}2.75 \pm \\
0.82\end{array}$ & $\begin{array}{c}8.43 \pm \\
1.44\end{array}$ & $\begin{array}{c}9.97 \pm \\
0.97\end{array}$ & $\begin{array}{c}0.07 \pm \\
0.04\end{array}$ & $\begin{array}{c}1.34 \pm \\
0.33\end{array}$ & $\begin{array}{c}0.29 \pm \\
0.02\end{array}$ & $\begin{array}{c}2.96 \pm \\
0.11\end{array}$ & $\begin{array}{c}3.7 \pm \\
0.74\end{array}$ & $\begin{array}{c}0.85 \pm \\
0.11\end{array}$ & $\begin{array}{c}0.53 \pm \\
0.11\end{array}$ & $\begin{array}{c}0.6 \pm \\
0.16\end{array}$ & $\begin{array}{c}20.4 \pm \\
1.91\end{array}$ \\
\hline BL_M & $\begin{array}{c}1810 \pm \\
73\end{array}$ & $0.2 \pm 0.1$ & $\begin{array}{c}0.12 \pm \\
0.01\end{array}$ & $\begin{array}{c}2.64 \pm \\
0.07\end{array}$ & $\begin{array}{c}3.81 \pm \\
0.16\end{array}$ & $\begin{array}{c}4.92 \pm \\
0.5\end{array}$ & $\begin{array}{c}0.04 \pm \\
0.02\end{array}$ & $\begin{array}{c}1.24 \pm \\
0.03\end{array}$ & $\begin{array}{c}0.17 \pm \\
0.01\end{array}$ & $\begin{array}{c}1.19 \pm \\
0.07\end{array}$ & $\begin{array}{c}2.05 \pm \\
1.41\end{array}$ & $\begin{array}{c}0.22 \pm \\
0.01\end{array}$ & $\begin{array}{c}0.39 \pm \\
0.07\end{array}$ & $\begin{array}{c}0.5 \pm \\
0.02\end{array}$ & $\begin{array}{c}11.4 \pm \\
0.59\end{array}$ \\
\hline
\end{tabular}


This result seems in contradiction with previous findings [18] in which the authors measured element contents in the same moss transplanted in bags and in Quercus ilex leaves, acting as short and long-term accumulators, respectively. They found that holm oak leaves showed contents about 10 folds those measured in the moss and concluded that the different exposure time could justify this difference. In the present work, instead, a higher content of elements was observed in the moss, irrespective of the different exposure time (sensibly higher in black locust leaves); this discrepancy could depend on the different leaf traits and properties of the two vascular plants. Quercus ilex indeed has numerous stellate trichomes and rough cuticle, likely providing large surfaces suitable for PM entrapment and adsorption [26]. Robinia pseudoacacia leaves (Figure 2) are instead quite smooth, both on abaxial (lower) and adaxial (upper) surfaces (Figure 2a,c), which show 10-13 trichomes per $\mathrm{mm}^{2}$, and a uniform, thinly ornamented waxy cover (Figure $2 b, d$ ).

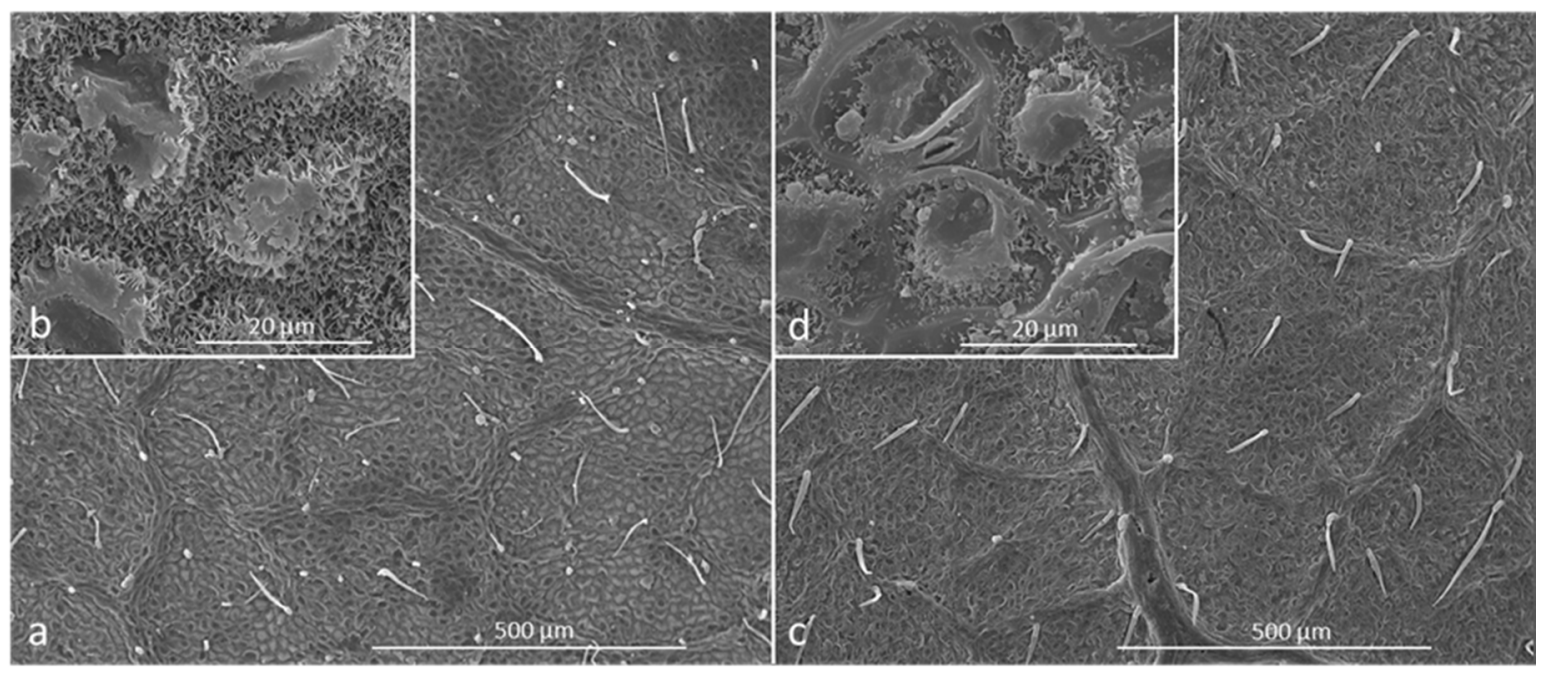

Figure 2. SEM micrographs of R. pseudoacacia leaves; adaxial surface (a,b); abaxial surface (c,d).

These features probably do not facilitate PM retention; it is worth noting that the leaves observed were collected at the end of vegetative season and their surfaces-having not undergone any chemical treatment-appeared clean, without particles. Accordingly, Al, an element considered a marker of soil resuspension, was significantly lower in R. pseudoacacia compared to moss, suggesting a scarce ability to entrap soil particles. In most of the tested sites, the only elements showing a significantly higher content in R. pseudoacacia were Mo-always one order of magnitude higher-and Zn (Table 1). Both elements are micronutrients and their higher concentration found in black locust leaves could be due to absorption via roots.

Hypnum cupressiforme was largely used in previous biomonitoring surveys, showing a marked capacity to intercept and retain PM, even after short exposure periods. Di Palma et al. [9] carried out a study focused on PM abundance and characterization on $H$. cupressiforme leaves; they found a particle number in 100,000 $\mu^{2}$ leaf surface $(10$ areas, $100 \times 100 \mu \mathrm{m})$ from hundreds to thousands, according to the different Countries (Austria, Italy and Spain) and land uses (agricultural, urban, industrial) of the exposure sites. In the same moss, it was observed that PM is tightly attached to leaf surface and difficult to remove [10]. These results can be related to the cell wall properties of this species, rich in carboxylic and phenolic groups, binding cations, including metals [12,13].

As for the possible pollution sources of the other accumulated elements, $\mathrm{Ce}$ and $\mathrm{Pb}$ are considered as markers of vehicular traffic for the emissions related to fuel, analytic converters, or the abrasion of engine components $[27,28]$. Furthermore, $\mathrm{Y}$ is an element attributable to residues from diesel engine thermal coatings (yttrium-stabilized zirconia) emitted by motor vehicles [29,30].

Arsenic can be linked to both natural (volcanic activity and erosion of volcanic rocks of Vesuvius and Phlegrean fields) and anthropogenic sources connected to agriculture (i.e., phytopharmaceuticals) [31]. 
Copper-based fungicides and bactericides are routinely used in agricultural practices; also, mineral and organic fertilizers are generally enriched in this element, representing a possible source of contamination when they are over-used [32].

$\mathrm{PM}$ of natural/crustal origin (i.e., containing $\mathrm{Al}, \mathrm{Ce}$, and $\mathrm{La}$ ) can be the source of these elements in moss and black locust leaves; the lanthanides $\mathrm{Ce}$ and $\mathrm{La}$ are freed into soil by the weathering of rocks and minerals, but are also drawn from REE-containing phosphate fertilizers and insect-fungicides [33,34].

$\mathrm{Cu}, \mathrm{Ni}, \mathrm{Pb}, \mathrm{Sb}$ and $\mathrm{Zn}$ can be found in dusts from wastes and residues of industrial manufacturing processes, as well as in exhaust and non-exhaust emissions linked to heavy duty vehicles (for example, diesel engine, brake wear emissions, erosion of asphalt and concrete-paved roads) [9,30].

Molybdenum is a micronutrient taken up by living organisms through nutrition; its concentration in the environment may rise due to anthropogenic activities, like coal combustion, municipal sewage sludge and industrial or mining operations [35].

The marked differences observed between the two biomonitors affect the total elemental load (Figure 3), which was always higher in H. cupressiforme than in R. pseudoacacia, indicating that most of the elements accumulated are of atmospheric origin.

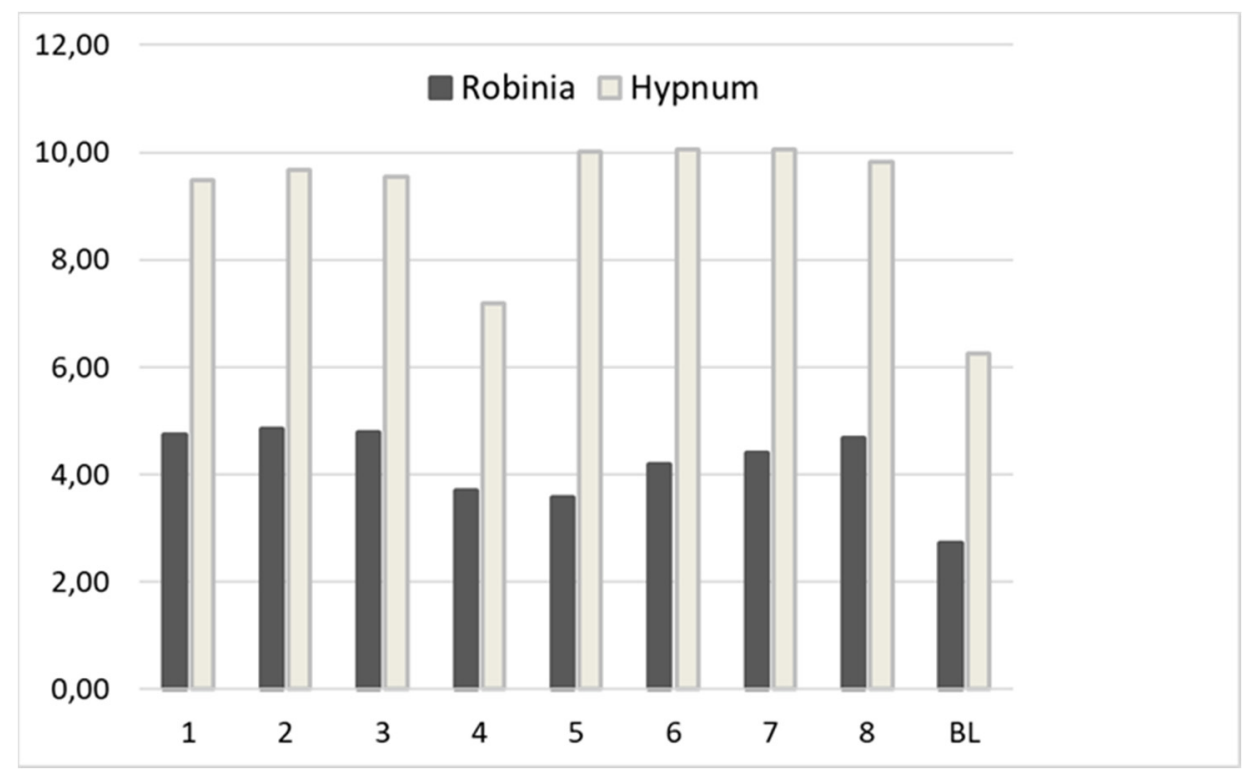

Figure 3. Normalized elemental load in R. pseudoacacia leaves and H. cupressiforme transplants in the eight sites. $\mathrm{BL}=$ baseline elemental load.

This difference is also evident in the baseline materials, i.e., those collected in proximal natural environments; in fact, the literature reports that in background areas, the average elemental content in the leaves of vascular plants is far lower than in mosses, sometimes with the difference approaching one order of magnitude [36]. This depends on the fact that moss chemical composition is much more affected by lithogenic elements (as $\mathrm{Al}, \mathrm{Fe}, \mathrm{Ti}$ ) and atmospheric long-range transport. Moreover, this result suggests that leaf traits, including surface features and texture, are of paramount importance in the entrapment ability of airborne pollutants, especially those linked to PM. Besides, the normalized elemental load also focuses a substantial homogeneity of the study area in terms of element uptake (Figure 3), with baseline contents (from plant material collected in pristine areas) lower than all the tested sites.

\subsection{Deposition Fluxes}

Based on a formula previously developed and used to assess PAH flux in moss and lichen transplants [24], deposition fluxes (Table 2) were calculated for the first time for metal(loid)s in moss and black locust. This parameter confirms the general trend observed for the contents, with higher 
values in moss compared to R. pseudoacacia; however, some elements-i.e., micronutrients Mo and Zn, and $\mathrm{Cr}$-showed a higher deposition flux in R. pseudoacacia.

Table 2. Daily flux $\left(\mu \mathrm{g} / \mathrm{m}^{2} \mathrm{~d}\right)$ of the target elements in R. pseudoacacia and H. cupressiforme. For Cr, Mo, Se and Zn flux values are higher in Robinia leaves; for all other elements except As flux is higher in the moss. For the elements BDL or lost during the exposure fluxes were not calculated.

\begin{tabular}{|c|c|c|c|c|c|c|c|c|c|c|c|c|c|c|c|}
\hline & Al & As & $\mathrm{Cd}$ & $\mathrm{Ce}$ & $\mathrm{Cr}$ & $\mathrm{Cu}$ & $\mathrm{Hg}$ & La & Mo & $\mathrm{Ni}$ & $\mathrm{Pb}$ & $\mathrm{Sb}$ & Se & $\mathbf{Y}$ & $\mathrm{Zn}$ \\
\hline 1_R & 25.25 & 0.0224 & 0.0017 & 0.0640 & 0.1852 & 0.7239 & 0.0039 & 0.0457 & 0.1167 & 0.0281 & 0.1554 & 0.0073 & 0.0421 & 0.0123 & 2.37 \\
\hline 2_R & 16.83 & 0.0421 & 0.0008 & 0.0396 & 0.3143 & 0.4442 & 0.0048 & 0.0171 & 0.2144 & 0.0295 & 0.1041 & 0.0098 & 0.0281 & 0.0064 & 2.07 \\
\hline 3_R & 36.47 & 0.0337 & 0.0008 & 0.0794 & 0.2525 & 0.5011 & 0.0036 & 0.0382 & 0.1504 & 0.0393 & 0.1658 & 0.0104 & 0.0337 & 0.0143 & 1.61 \\
\hline 5_R & 36.20 & 0.0253 & 0.0008 & 0.0115 & 0.2385 & 0.5578 & 0.0017 & 0.0051 & 0.2183 & 0.0337 & 0.0544 & 0.0036 & 0.0281 & 0.0024 & 2.11 \\
\hline 6_R & 15.19 & 0.0084 & 0.0008 & 0.0476 & 0.2231 & 0.7269 & 0.0028 & 0.0463 & 0.3026 & 0.0589 & 0.0463 & 0.0126 & 0.0084 & 0.0114 & 5.34 \\
\hline 7_R & 14.02 & 0.0309 & 0.0008 & 0.0415 & 0.2273 & 0.5825 & 0.0028 & 0.0244 & 0.2006 & 0.0673 & 0.0730 & 0.0199 & 0.0224 & 0.0098 & 2.64 \\
\hline 1_ $\overline{\mathbf{M}}$ & 98.17 & 0.0265 & 0.0024 & 0.2295 & 0.0218 & 1.2339 & 0.0017 & 0.1233 & 0.0106 & 0.0899 & 0.5802 & 0.1061 & 0.0135 & 0.0449 & 1.62 \\
\hline 2_M & 98.17 & 0.0265 & 0.0029 & 0.2077 & - & 1.4291 & 0.0016 & 0.1186 & 0.0189 & 0.0841 & 0.8030 & 0.1190 & 0.0135 & 0.0512 & 1.15 \\
\hline 3_M & 62.90 & 0.0529 & 0.0006 & 0.2089 & - & 1.1075 & 0.0004 & 0.1162 & 0.0183 & 0.0664 & 0.8924 & 0.1184 & 0.0135 & 0.0373 & 0.97 \\
\hline 4_M & - & 0.0000 & - & 0.0137 & - & 0.5155 & 0.0019 & 0.0039 & 0.0077 & 0.0723 & 0.1863 & 0.0755 & - & 0.0077 & 1.57 \\
\hline 5_M & 51.14 & 0.0176 & 0.0053 & 0.1330 & 0.0159 & 1.0858 & 0.0023 & 0.0721 & 0.0165 & 0.2016 & 0.8001 & 0.0978 & - & 0.0507 & 15.23 \\
\hline 6_M & 139.32 & 0.0000 & 0.0006 & 0.3529 & - & 0.7036 & 0.0027 & 0.1738 & 0.0124 & 0.0899 & 0.4179 & 0.1643 & 0.0135 & 0.0851 & 6.17 \\
\hline
\end{tabular}

This could depend on the chemical form and bioavailability in the environment of these elements; in fact, for black locust, two ways of uptake do exist-via roots by absorption, and via leaves by deposition on the leaf surface and entrance through stomata. Therefore, moss confirms its ability to accumulate inorganic pollutants through the interception and retention of PM, taking advantage of the enhanced surface to mass ratio (SLA) and the peculiar cell wall properties [13], differently from R. pseudoacacia, in which only the elements bioavailable in the soil show better fluxes.

\section{Conclusions}

This work, investigating the metal uptake ability in native black locust and moss bags, evidenced a different behavior of the two species. Specifically, our results confirm that mosses are powerful bioaccumulators of airborne elements; instead, black locust leaves show a reduced element accumulation. Unlike with $H$. cupressiforme and other vascular plants used in biomonitoring studies, R. pseudoacacia exhibits a limited ability to intercept and retain particulate matter, likely due to leaf traits and micromorphology with scarce trichomes and smooth leaf surface. Therefore, the choice of the right species for the target pollutants must consider the leaf traits and surface micromorphology and properties; under these respects, black locust showed a limited performance, despite the wide distribution of this tree in temperate and impacted environments. Hence, if the aim of the survey is the evaluation of atmospheric inputs, the moss-bag approach represents the winning choice; otherwise, if the objective of the study is collecting information from the whole environment, vascular plants can be more reliable. All the investigated sites show similar environmental contributions, suggesting that the studied area is largely homogeneous, and the major inputs are represented by agricultural, productive and transport activities. Despite the higher sensitivity of the moss, the two biomonitors display a similar environmental impact over the entire study area; the different sensitivity affects element accumulation and flux-generally higher in the moss. Finally, the deposition flux can be considered a proxy for the inter-comparability of different species used in biomonitoring, and even between biomonitors and bulk deposimeters.

Supplementary Materials: The following are available online at http://www.mdpi.com/2073-4433/11/2/148/s1, Table S1, title: Geographical coordinates of exposure and collection sites; Figure S1: Satellite view of the target sites selected in Campania Region (southern Italy). Image obtained by Google Earth Pro 2020. 
Author Contributions: Conceptualization, F.C., P.A., S.G. and V.S.; methodology, F.C., M.C.S., A.D.P.; software, F.C.; formal analysis, F.C., M.C.S., A.D.P.; investigation, F.C. and A.D.P.; resources, V.S. and P.A.; data curation, F.C.; original draft preparation, F.C., P.A., S.G. and V.S.; review and editing, F.C., S.G. and V.S.; supervision, F.C., S.G. and V.S. All authors have read and agreed to the published version of the manuscript.

Funding: This research received no external funding.

Acknowledgments: We kindly thanks Sergio Sorbo for his support in SEM observations.

Conflicts of Interest: The authors declare no conflict of interest.

\section{References}

1. Wolterbeek, B. Biomonitoring of trace element air pollution: Principles, possibilities and perspectives. Environ. Pollut. 2002, 120, 11-21. [CrossRef]

2. Augusto, S.; Pereira, M.J.; Maguas, C.; Branquinho, C. A step towards the use of biomonitors as estimators of atmospheric PAHs for regulatory purposes. Chemosphere 2013, 92, 626-632. [CrossRef] [PubMed]

3. Capozzi, F.; Giordano, S.; Di Palma, A.; Spagnuolo, V.; De Nicola, F.; Adamo, P. Biomonitoring of atmospheric pollution by moss bags: Discriminating urban-rural structure in a fragmented landscape. Chemosphere 2016, 149, 211-218. [CrossRef] [PubMed]

4. Di Palma, A.; Crespo Pardo, D.; Spagnuolo, V.; Adamo, P.; Bargagli, R.; Cafasso, D.; Capozzi, F.; Aboal, J.R.; Gonzalez, A.G.; Pokrovsky, O.; et al. Molecular and chemical characterization of a Sphagnum palustre clone: Key steps Towards a standardized and sustainable moss bag technique. Ecol. Indic. 2016, 71, 388-397. [CrossRef]

5. Harmens, H.; Foan, L.; Simon, V.; Mills, G. Mosses as biomonitors of atmospheric POPs pollution: A review. Environ. Pollut. 2013, 173, 245-254. [CrossRef]

6. Kodnik, D.; Candotto Carniel, F.; Licen, S.; Tolloi, A.; Barbieri, P.; Tretiach, M. Seasonal variations of PAHs content and distribution patterns in a mixed land use area: A case study in NE Italy with the transplanted lichen Pseudevernia furfuracea. Atmos. Environ. 2015, 113, 255-263. [CrossRef]

7. Chao, C.Y.; Wong, K.K. Residential indoor $\mathrm{PM}_{10}$ and $\mathrm{PM}_{2.5}$ in Hong Kong and the elemental composition. Atmos. Environ. 2002, 36, 265-277. [CrossRef]

8. Chen, X.G.; Fan, S.J. Characteristics of indoor/outdoor $\mathrm{PM}_{2.5}$ and elemental components in generic urban, roadside and industrial plant areas of Guangzhou City, China. J. Environ. Sci. 2007, 19, 35-43.

9. Di Palma, A.; Capozzi, F.; Spagnuolo, V.; Adamo, P.; Giordano, S. Atmospheric particulate matter intercepted by moss-bags: Relations to moss trace element uptake and land use. Chemosphere 2017, 176, 361-368. [CrossRef]

10. Spagnuolo, V.; Giordano, S.; Perez-Llamazares, A.; Ares, A.; Carballeira, A.; Fernandez, J.A.; Aboal, J.R. Distinguishing metal bioconcentration from PM in moss tissue: Testing methods of removing particles attached to the moss surface. Sci. Total Environ. 2013, 463-464, 727-733. [CrossRef]

11. Capozzi, F.; Di Palma, A.; Adamo, P.; Sorrentino, M.C.; Giordano, S.; Spagnuolo, V. Indoor vs. outdoor airborne element array: A novel approach using moss bags to explore possible pollution sources. Environ. Pollut. 2019, 249, 566-572. [CrossRef] [PubMed]

12. Gonzalez, A.G.; Pokrovsky, O.S. Metal adsorption on mosses: Toward a universal adsorption model. J. Colloid Interf. Sci. 2014, 415, 169-178. [CrossRef] [PubMed]

13. Gonzalez, A.G.; Pokrovsky, O.S.; Beike, K.A.; Reski, R.; Di Palma, A.; Adamo, P.; Giordano, S.; Fernandez, J.A. Metal and proton adsorption capacities of natural and cloned Sphagnum mosses. J. Colloid Interf. Sci. 2016, 461, 326-334. [CrossRef] [PubMed]

14. Tretiach, M.; Adamo, P.; Bargagli, R.; Baruffo, L.; Carletti, L.; Crisafulli, P.; Giordano, S.; Modenesi, P.; Orlando, S.; Pittao, E. Lichen and moss bags as monitoring devices in urban areas. Part I: Influence of exposure on vitality. Environ. Pollut. 2007, 146, 380-391. [CrossRef] [PubMed]

15. Adamo, P.; Giordano, S.; Sforza, A.; Bargagli, R. Implementation of airborne trace element monitoring with devitalised transplants of Hypnum cupressiforme Hedw.: Assessment of temporal trends and element contribution by vehicular traffic in Naples city. Environ. Pollut. 2011, 159, 1620-1628. [CrossRef]

16. Beike, A.K.; Spagnuolo, V.; Lüth, V.; Steinhart, F.; Ramos-Gomez, J.; Krebs, M.; Adamo, P.; Rey-Asensio, A.I.; Fernàndez, J.A.; Giordano, S.; et al. Clonal in vitro propagation of peat mosses (Sphagnum, L.) as novel green resources for basic and applied research. Plant Cell Tissue Organ. Cult. 2015, 120, 1037-1049. [CrossRef] 
17. Capozzi, F.; Giordano, S.; Aboal, J.R.; Adamo, P.; Bargagli, R.; Boquete, T.; Di Palma, A.; Real, C.; Reski, R.; Spagnuolo, V.; et al. Best options for the exposure of traditional and innovative moss bags: A systematic evaluation in three European countries. Environ. Pollut. 2016, 214, 362-373. [CrossRef]

18. De Nicola, F.; Murena, F.; Costagliola, M.A.; Alfani, A.; Baldantoni, D.; Prati, M.V.; Sessa, L.; Spagnuolo, V.; Giordano, S. A multi-approach monitoring of particulate matter, metals and PAHs in an urban street canyon. Environ. Sci. Pollut. Res. 2013, 20, 4969-4979. [CrossRef]

19. Ares, A.; Aboal, J.R.; Carballeira, A.; Giordano, S.; Adamo, P.; Fernandez, J.A. Moss bag biomonitoring: A methodological review. Sci. Total Environ. 2012, 432, 143-158. [CrossRef]

20. Tzvetkova, N.; Petkova, K. Bioaccumulation of heavy metals by leaves of R. pseudoacacia as a bioindicator tree in industrial zones. J. Environ. Biol. 2015, 36, 59-63.

21. Capozzi, F.; Di Palma, A.; Adamo, P.; Spagnuolo, V.; Giordano, S. Monitoring chronic and acute PAH atmospheric pollution using transplants of the moss Hypnum cupressiforme and Robinia pseudoacacia leaves. Atmos. Environ. 2017, 150, 45-54. [CrossRef]

22. Steinnes, E.; Rühling, Å.; Lippo, H.; Makinen, A. Reference materials for large scale metal deposition surveys. Accred. Qual. Assur. 1997, 2, 243-249. [CrossRef]

23. Wilcoxon, F. Individual comparisons by ranking methods. Biometrics Bull. 1945, 1, 80-83. [CrossRef]

24. Capozzi, F.; Sorrentino, M.C.; Di Palma, A.; Mele, F.; Arena, C.; Adamo, P.; Spagnuolo, V.; Giordano, S. Implication of vitality, seasonality and specific leaf area on PAH uptake in moss and lichen transplanted in bags. Ecol. Indic. 2020, 108, 105727. [CrossRef]

25. Reich, P.B.; Ellsworth, D.S.; Walters, M.B.; Vose, J.M.; Gresham, C.; Volin, J.C.; Bowman, W.D. Generality of leaf trait relationships: A test across six biomes. Ecology 1999, 80, 1955-1969. [CrossRef]

26. Bussotti, F.; Grossoni, P. European and Mediterranean oaks (Quercus, L.; Fagaceae): SEM characterization of the micromorphology of the abaxial leaf surface. Bot. J. Linn. Soc. 1997, 124, 183-199. [CrossRef]

27. Hueglin, C.; Gehrig, R.; Baltensperger, U.; Gysel, M.; Monn, C.; Vonmont, H. Chemical characterisation of $\mathrm{PM}_{2.5}, \mathrm{PM}_{10}$ and coarse particles at urban, nearcity and rural sites in Switzerland. Atmos. Environ. 2005, 39, 637-651. [CrossRef]

28. Pant, P.; Harrison, R.M. Estimation of the contribution of road traffic emissions to particulate matter concentrations from field measurements: A review. Atmos. Environ. 2013, 77, 78-97. [CrossRef]

29. Hejwowski, T.; Weronski, A. The effect of thermal barrier coating on diesel engine performance. Vacuum 2002, 65, 427-432. [CrossRef]

30. Thorpe, A.; Harrison, R.M. Sources and properties of non-exhaust particulate matter from road traffic: A review. Sci. Total Environ. 2008, 400, 270-282. [CrossRef]

31. Arpadjan, S.; Celik, G.; Taskesen, S.; Gucer, S. Arsenic, cadmium and lead in medicinal herbs and their fractionation. Food Chem. Toxicol. 2008, 46, 2871-2875. [CrossRef] [PubMed]

32. Brunetto, G.; Bastos de Melo, G.W.; Terzano, R.; Del Buono, D.; Astolfi, S.; Tomasi, N.; Pii, Y.; Mimmo, T.; Cesco, S. Copper accumulation in vineyard soils: Rhizosphere processes and agronomic practices to limit its toxicity. Chemosphere 2016, 162, 293-307. [CrossRef] [PubMed]

33. Carpenter, D.; Boutin, C.; Allison, J.E.; Parsons, J.L.; Ellis, D.M. Uptake and effects of six rare earth elements (REEs) on selected native and crop species growing in contaminated soils. PLoS ONE 2015, 10, 0129936. [CrossRef] [PubMed]

34. Kabata-Pendias, A. Trace Elements in Soils and Plants, 4th ed.; CRC Press: Boca Raton, FL, USA, $2010 ;$ p. 534.

35. Barceloux, D.G.; Barceloux, D. Molybdenum. J. Toxicol. Clin. Tox. 1999, 37, 231-237. [CrossRef] [PubMed]

36. Bargagli, R. Trace Elements in Terrestrial Plants. An Ecophysiological Approach to Biomonitoring and Biorecovery; Springer-Verlag: Berlin, Germany, 1998; p. 324.

(C) 2020 by the authors. Licensee MDPI, Basel, Switzerland. This article is an open access article distributed under the terms and conditions of the Creative Commons Attribution (CC BY) license (http://creativecommons.org/licenses/by/4.0/). 